\title{
Democracia, Populismos, Revolucionarismos
}

\author{
Walnice Nogueira Galvão \\ Universidade de São Paulo | São Paulo | Brasil \\ Professora Emérita da Faculdade de Filosofia, Letras e Ciências Humanas
}

Ao atentar para esta preocupação com democracia e populismo (talvez mais candentes neste país do que "revolucionarismo" - mas nem por isso sua crítica se torna menos crucial), fico pensando qual seria o lugar dos meios de comunicação de massas.

Porque me parece que hoje uma reflexão sobre esses três temas passa necessariamente pela mídia. O que talvez não ocorra em outros lugares do mundo, sobretudo Europa e Estados Unidos — mas mesmo lá há que interrogar-se porque uma aberração como Rupert Murdoch não só existe como ainda prospera. Como vivemos num país onde a mídia é oligopólica, pertencendo a apenas quatro famílias, e de direita, não havendo nenhuma participação de qualquer outra tonalidade do espectro político, o papel que desempenha é ponderável.

Por isso, gostaria de lembrar dois pontos. Primeiro, na gestão democrática Vargas, quando o ex-ditador voltou à presidência pelo voto, uma aliança golpista entre mídia, classe dominante e militares se encarniçou contra ele. Mesmo assim, tinha tido o cuidado de ter completamente a seu favor um jornal bom de briga, que era a Última Hora, muito popular, e a rádio de maior audiência do país, a Rádio Nacional. Isso foi antes da era da Tv e o líder da aliança era dono de jornal. Ainda assim, a aliança levou Vargas à queda, o que resultou em seu suicídio. Mais tarde, o mesmo jornal que o apoiara seria o suporte do governo Jango, deposto pelo golpe de 1964 .

Segundo ponto: nestes doze últimos anos de governo de esquerda, a mídia totalitária fortaleceu-se e dominou o panorama de maneira nunca vista, fazendo lavagem cerebral incessante e sem o menor escrúpulo, pautando, como todos sabem, até a conduta do Judiciário. Nem os partidos nem os governos de esquerda cuidaram de ter um jornal, uma revista, uma rádio, uma estação de TV que fosse, ou uma presença forte na internet, para poder engajar debate e responder às gravíssimas e diárias acusações. Resultado: todo mundo dá fé a estas, porque ficam 
sem resposta. E as ameaças de um impeachment absurdo se acumulam em cima de uma perda de popularidade que foi cuidadosamente construída pela oposição ao longo dos últimos dez anos, pois foi em 2005 que vieram à tona as primeiras denúncias de corrupção. A tal ponto que hoje é crença generalizada (e em São Paulo nem se fala) que só existe $u m$ partido corrupto e que a corrupção desse partido é o único problema do país.

Meu interesse pela mídia vem de longe. Quando estudei a representação jornalística da Guerra de Canudos, fiquei espantada ao verificar a unanimidade criminosa dos jornais, mesmo os mais sérios, e sua pressa em acusar os canudenses — um punhado de gente miserável e desarmada — de liderarem uma conspiração internacional que visava à restauração do trono. Datava de apenas alguns anos o advento da República. E todos preconizavam a mesma medida: extermínio. A publicação de notícias falsas e mesmo de documentos forjados era geral, e ninguém ligava, porque não havia ninguém para defender os canudenses nem canal de mídia que deles se ocupasse. Isso foi antes do rádio e da TV, só havia jornal.

Foi um trabalho que não fiz à toa. Era o pior período da ditadura militar e eu queria tomar uma iniciativa que, mesmo que modesta e contida nos muros da universidade, tratasse de algo que se via todos os dias: notícias falsas referentes aos guerrilheiros que se opunham ao regime (falsas delaçóes de arrependidos, falsas mortes por acidentes em fuga, falsas revelaçōes e documentos), para desmoralizá-los. E que mostrasse as forças armadas sob seu pior aspecto, de carrasco dos oprimidos, em aliança com uma mídia subserviente e desonesta.

Pois bem: não estou vendo nada de muito diferente, nesse aspecto, na atualidade - menos os militares, espero.

Por isso, dirigiria uma mesma e única pergunta aos três expositores. Ou seja: como discutir as relaçōes entre democracia e populismo sem passar pela mídia? Ou melhor: haveria condiçôes de possibilidade de uma mídia — já não digo livre, mas plural - numa democracia às turras com o populismo? E ainda: no que as perquiriçôes de Lefort podem nos ajudar a investigar melhor o papel da mídia nessas relações? Ele, a quem eram tão caras a desincorporação do poder e a indeterminação da democracia, o que pensaria de uma mídia totalitária. E a quem eram tão caros o Brasil e os brasileiros.

Mil perdóes por lançar lenha na fogueira no apagar das luzes, no último minuto de um congresso que tomou vários dias, quando todo mundo está querendo ir embora e descansar. Se quiserem cancelar o debate, em atenção ao muito que já trabalharam, estarei de acordo. 